INTER NATIONAL MONETARY FUND

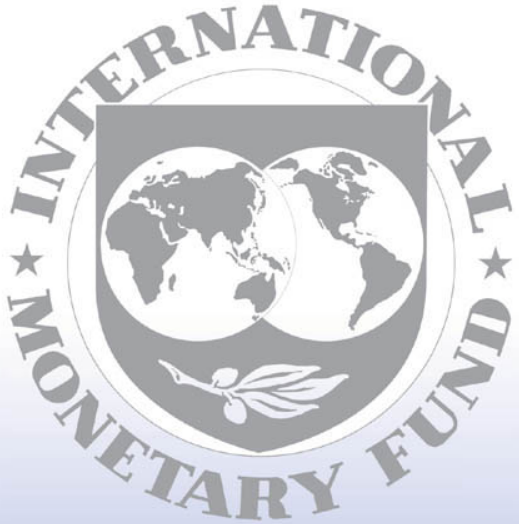

Staff

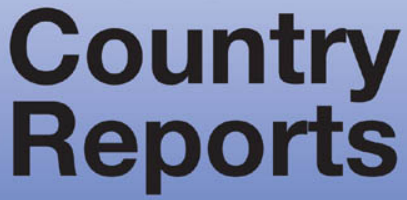




\section{Ireland: Report on the Observance of Standards and Codes- FATF Recommendations for Anti-Money Laundering and Combating the Financing of Terrorism}

This Report on the Observance of Standards and Codes on the FATF Recommendations for Anti-Money Laundering and Combating the Financing of Terrorism for Ireland was prepared by the Financial Action Task Force on Money Laundering (FATF), using the assessment methodology adopted by the FATF in February 2004 and endorsed by the Executive Board of the IMF in March 2004. The views expressed in this document, as well as in the full assessment report, are those of the FATF and do not necessarily reflect the views of the government of Ireland or the Executive Board of the IMF.

A copy of the full assessment report can be found on the website of the FATF at http://www.fatf-gafi.org/dataoecd/63/29/36336845.pdf

To assist the IMF in evaluating the publication policy, reader comments are invited and may be sent by e-mail to publicationpolicy@imf.org. 
This page intentionally left blank 


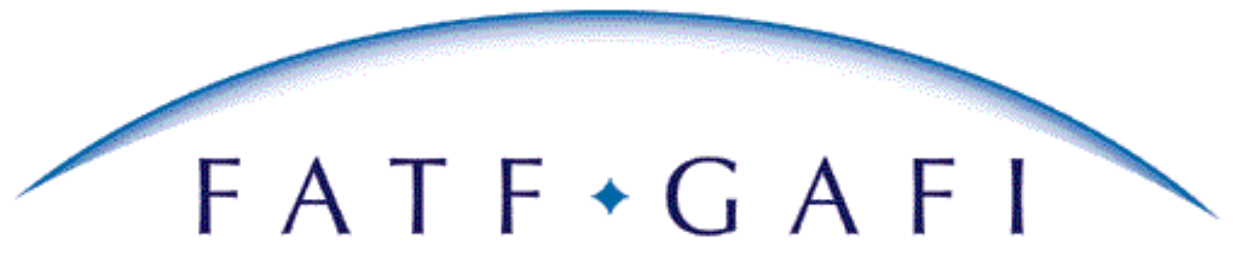

\section{Financial Action Task Force Groupe d'action financière}

\section{IRELAND}

Report on Observance of Standards and Codes

FATF Recommendations for Anti-Money Laundering and Combating the Financing of Terrorism

(C) 2006 FATF/OECD. All rights reserved. 


\title{
RePort on Observance OF STANDARDS AND Codes
}

\section{FATF Recommendations for Anti-Money Laundering and Combating the Financing of Terrorism}

\author{
IRELAND
}

\section{Background Information}

1. This Report on the Observance of Standards and Codes for the FATF 40 Recommendations for Anti-Money Laundering and 9 Special Recommendations Combating the Financing of Terrorism was prepared by the Financial Action Task Force. The report provides a summary ${ }^{1}$ of the AML/CFT measures in place in Ireland as at July 2005 (the date of the on-site visit). The report describes and analyses those measures and provides recommendations on how certain aspects of the system could be strengthened. The views expressed in this document have been agreed by the FATF and Ireland, but do not necessarily reflect the views of the Boards of the IMF or World Bank. The Irish Government recognises the need for an effective AML/CFT regime and is currently updating its legislation to implement the revised FATF Recommendations.

2. This report provides a summary of the AML/CFT measures in place in Ireland at July 2005 (the date of the on-site visit). The report describes and analyses those measures and provides recommendations on how certain aspects of the system could be strengthened. It also sets out Ireland's levels of compliance with the FATF $40+9$ Recommendations (see attached table on the Ratings of Compliance with the FATF Recommendations). The Irish Government recognises the need for an effective AML/CFT regime and is in the process of updating its ML/TF framework.

3. Narcotics offences provide a substantial source of the proceeds of crime in Ireland; considerable illegal proceeds are also derived from fraud-related offences, tax evasion, the evading of excise duties (taking advantage of price differentials from higher rates of excise duty in Northern Ireland) and criminal activity associated with terrorism.

4. Criminals, including terrorists, have used a variety of techniques to launder money. Irish authorities have noted that increasingly money launderers have used financial institutions, businesses or professions that are either not regulated or have a low compliance culture for AML to launder money. Investigations have indicated that credit institutions, money remittance companies, solicitors, accountants and second hand car dealerships have all been used in ML schemes.

5. Ireland has a modern, international financial services sector and a wide range of financial services and institutions operate from the jurisdiction. Depository corporations (such as banks, building societies and credit unions); financial markets (exchanges); insurance corporations and pension funds (life insurance and general insurance); other financial corporations, including financial intermediaries (such as Agency Fund Managers, investment business firms and stockbrokers); financial auxiliaries (such as insurance brokers); and money remittance dealers and bureaux de change.

6. A full range of Designated Non-Financial Businesses and Professions (DNFBPs) operate in Ireland: Real estate agents/auctioneers, dealers in precious metals and stones, lawyers (solicitors and barristers), accountants and trust and company service providers. There are also a number of private clubs that provide casino type gaming facilities.

7. Ireland is a republic, with a parliamentary system of government and a common law legal system with a Constitution. The Department of Justice, Equality and Law Reform is responsible for

\footnotetext{
${ }^{1}$ A copy of the full Mutual Evaluation Report can be found on the FATF website: www.fatf-gafi.org.
} 
the development and implementation of the criminal law. The Department of Finance is responsible for policy and legislative implementation in relation to the financial sector.

\section{Legal System and Related Institutional Measures}

8. Ireland has a broad money laundering (ML) offence, which meets the FATF requirements; however the number of ML prosecutions and convictions remains low. ML is criminalised under the Criminal Justice Act (CJA) (1994) which had been in effect since 1994, and since 2001 the ML offence has applied to all indictable offences. Penalties under the CJA 1994 apply to both natural and legal persons under s.59 of the Act.

9. The offence of Terrorist Financing (TF) was established by the Criminal Justice (Terrorist Offences) Act (2005) and TF offences are also predicate offences for ML. The TF offence is criminalised in accordance with the provisions of the UN Convention for the Suppression of TF and UN S/RES/1373 (2001). The TF offence, however, does not currently cover the funding of a single terrorist or two terrorists acting in concert.

10. Between 2001 and 2004 inclusive, 15 people were charged with ML and 8 people have been convicted. Sentences being handed down on conviction generally appear appropriate (from 2 to 5 years imprisonment). There have been a relatively low number of convictions. A lack of comprehensive statistics on ML investigations, prosecutions and convictions prevents a full evaluation of effectiveness. There have been no prosecutions for TF since the offence was only implemented in March 2005.

11. Ireland's provisions for the confiscation of the proceeds of crime appear effective and comprehensive, and are available through both criminal and civil procedures. The CJA (1994) provides that where a person is convicted of any offence on indictment the court can require the payment of the person's benefits from crime. Between 2001 to 2004 freezing and confiscation measures under the CJA (1994) were taken in 14 cases covering a total amount of $€ 800,000$. In addition to conviction based confiscation, the Proceeds of Crime Act (1996) provides for the civil forfeiture of property which is shown, on the balance of probabilities, to be the proceeds of crime. Between 2001 and 2004 property to the approximate value of $€ 43$ million was frozen. The Criminal Justice (Terrorist Offences) Act (2005) provides the legislative basis for confiscation orders relating to the offence of TF.

12. Ireland has measures for the freezing of terrorist funds and has implemented UN Security Council Resolutions 1267 (1999) and 1373 (2001) under EU Council Regulations. These have direct force of law in Ireland and financial institutions are required to freeze assets from the date of such EU Regulations. Regulations made under the Criminal Justice (Terrorist Offences) Act (2005) further provide for penalties for non-compliance. This process is largely effective in informing the financial sector of their freezing obligations.

13. The Garda Bureau of Fraud Investigation (GBFI) hosts the FIU, which was established in 1995. The FIU receives STRs and after assessment disseminates them to financial investigation units within the Garda for further investigation. The FIU shares responsibility for the receipt of STRs with the Revenue Commissioners which investigates STRs in relation to possible tax /customs offences. The number of STRs received by the FIU has increased from 3,040 in 2001 to 5,491 in 2004, and 10,735 were received during 2005. The resources available to the FIU to effectively manage and conduct analysis on the increasing numbers of STRs, while also performing its other AML/CFT responsibilities are limited.

14. Adequate powers are available to the Garda, the $\mathrm{CAB}$ and Revenue Commissioners to gather evidence and compel the production of financial records and files from financial institutions and DNFBPs. The Irish authorities have sufficient powers to prosecute ML and TF offences; however the 
structures, staffing and resources to investigate these offences are also responsible for examining a range of white collar crimes. While legal measures are available to investigate and prosecute for ML or TF offences few cases lead to a successful prosecution.

\section{$3 \quad$ Preventive Measures - Financial Institutions}

15. The CJA (1994) (as amended) defines those financial institutions that are subject to AML/CFT obligations, classifying them as designated bodies under the Act. Designated bodies include all relevant financial institutions as defined. Designated bodies are obliged under s. 32(2) of CJA (1994) to identify customers, to retain records in relation to customers and transactions, to adopt measures to prevent and detect ML and TF - including training employees and detecting and reporting suspicious transactions. The Irish legislative framework does not impose AML/CFT obligations on the basis of risk.

16. The requirements to conduct Customer Due Diligence (CDD) are met in part from the CJA (1994). Designated bodies are required to take reasonable measures to identify customers when establishing business relationships or when performing transactions over $€ 13,000$. These provisions also apply to identifying/verifying relationships established for legal persons or arrangements. No explicit provision requires the identity of the beneficial owner to be established and verified, nor does the legislation impose other CDD requirements. The application of s.32 of the CJA (1994) does not extend to those customers that had existing business relations prior to May 1995 except in cases where it is suspected that a service is connected with the commission of a money laundering offence. More extended CDD measures are outlined in guidance notes, however the guidance does not impose a directly enforceable legal obligation with adequate sanctions.

17. Section 32(6) of the CJA (1994) provides exemptions from CDD requirements where a customer is another designated body, or is corresponding body in an EU Member State or another prescribed state or country. All non-EU FATF countries, Liechtenstein, the Channel Islands and the Isle of Man have been prescribed. Despite this, the evaluation team were informed identification procedures are performed in practice regardless of whether a counterpart is a designated body or not.

18. There are no specific obligations regarding higher risk relationships for politically exposed persons (PEPs), correspondent banking or for financial institutions to have policies in place to prevent the misuse of technological developments in ML/TF. AML/CFT obligations on introduced business within the financial sector are currently contained in guidance.

19. Sectoral guidance notes complement the AML obligations under the CJA (1994) and provide additional more detailed information for the banking, securities, stockbroking insurance sectors and credit unions on how to implement AML/CFT measures. The guidance notes are issued by the Money Laundering Steering Committee (MLSC), which is made up of different government agencies and private sector bodies. The guidance notes provide an explanation on the requirements of the CJA (1994) and its amendments; provide a steer on internal controls, policies and procedures as well as dealing with many aspects of CDD, record keeping, STR reporting and education and training procedures. Guidance to financial institutions has also been provided in relation to TF after the enactment of the Criminal Justice (Terrorist Offences) Act (2005).

20. The guidance notes are comprehensive and provide financial institutions with a thorough explanation of how they could apply appropriate AML/CFT controls. However, the guidance notes do not impose mandatory requirements with sanctions for non-compliance as required by the FATF Recommendations.

21. Banking secrecy does not inhibit the implementation of the FATF Recommendations. The Irish AML/CFT framework appropriately reconciles the right to confidentiality of financial institutions' 
customers with competent authorities' need to access the information they may require to fulfil their AML/CFT duties.

22. Designated bodies are required under the CJA (1994) to keep records in relation to customer identification for five years after the business relationship has ended, and for transactions for five years after the date of the transaction. In addition, there are specific provisions requiring that companies/firms comply with explicit record and book-keeping requirements which are set out under legislation such as Companies Acts (1963 and 1990), Central Bank Acts (1989 and 1997), the Investment Intermediaries Act, 1995 and the Stock Exchange Act, 1995. There are no provisions imposing specific information gathering, retention and onward transmission requirements with reference to wire transfers under Special Recommendation VII.

23. There is no explicit requirement to pay attention to all unusual, complex large transactions and transactions with no visible economic purposes, nor to further examine these situations and to set out these findings in writing. The guidance notes do however provide some assistance to designated bodies in recognising transactions that are potentially suspicious. The Financial Regulator distributes information on NCCT countries to financial institutions. The CJA (1994) also allows the Minister for Justice to designate countries where appropriate measures for the prevention and detection of ML have not been implemented. Countries are designated when counter measures are applied by FATF. Ireland recently revoked designations on the two outstanding countries (Myanmar and Nauru) which had counter measures removed from them.

24. Section 57 (1) of the CJA (1994) requires a designated body to report to the Garda and the Revenue Commissioners where they suspect that a ML offence has been or is being committed. The obligation to report also applies to any infringement of the AML/CFT preventive measures set out in s.32 of the CJA (1994). Section 36 of the Criminal Justice (Terrorist Offences) Act (2005) amended section 57 of the CJA (1994) and creates an obligation for designated bodies to report to the Garda and Revenue suspicions that an offence of TF has been or is being committed. Overall, the number of STRs received (see above) is comparable to other similarly sized jurisdictions, and comes from a range of different types of financial institutions. The number of STRs has risen over time as legislation has extended STR obligations and the number of reports received appears to be generally satisfactory. Reports are also being made in relation to suspected cases of TF.

25. The CJA (1994) imposes a general requirement on designated bodies to adopt measures to prevent and detect ML, and s.32 of the Criminal Justice (Terrorist Offences) Act (2005) extends this provision to include TF. Measures must include the establishment of procedures to be followed by employees in the conduct of business; and providing employees with instructions on the application AML measures. The guidance notes deal with more detailed measures - developing compliance management arrangements such as the appointment of a Money Laundering Reporting Officer (MLRO); ensuring the MLRO has access to relevant information; procedures for internal and onward reporting of suspicions and testing these procedures. Staff training is required under s.32 (9B) of the CJA (1994) and directors and mangers have to go through fit and proper checks by the Financial Regulator.

26. In relation to foreign branches and subsidiaries, the guidance notes recommend that a group policy be established to ensure that where possible overseas operations comply at a minimum with the standards set out in the Irish guidance notes. Legislation allows the exchanging of information when a supervisor may observe that a branch or subsidiary is unable to observe AML/CFT standards. However, this could be strengthened by requiring that particular attention should be paid to branches and subsidiaries in countries that do not, or insufficiently, apply the FATF Recommendations.

27. The banking authorisation process in Ireland effectively precludes the establishment and operation of "shell banks" within Ireland. However, Ireland does not prohibit financial institutions from entering into correspondent banking relationships with shell banks, nor do they need to satisfy 
themselves that respondent financial institutions in a foreign country do not permit their accounts to be used by shell banks.

28. As noted above, there are several sets of guidance notes that provide additional information on how financial institutions can, in practice, apply record keeping, internal controls and STR reporting requirements and the evaluation team found that in practice, financial institutions often adopted measures that are stricter than those posed in the guidance.

29. The Irish Financial Services Regulatory Authority, known as the Financial Regulator applies strict licensing and supervision requirements before authorizing financial institutions to become active in Ireland. Applications for authorisation must include detailed information on ownership including legal form and structure and this information is checked as part of a "fit and proper" review. The Financial Regulator is responsible for supervising and monitoring financial institutions for compliance with the Core Principles (in the banking, insurance and securities sectors), as well as compliance with AML/CFT legislation. On-site inspections are a significant component of an active monitoring process which seeks to confirm that all financial service providers operate within the terms of their authorisation.

30. Ireland follows a principles-based approach to regulation and supervision, placing responsibility on the boards and management of financial institutions to implement appropriate risk management systems and effective AML/CFT internal controls. The fitness and probity of those who manage financial institutions is monitored closely by the Financial Regulator.

31. The Financial Regulator requires designated bodies to take all necessary measures to effectively counteract ML and TF in accordance with the CJA (1994) and Criminal Justice (Terrorist Offences) Act (2005) and the relevant sectoral guidance notes. The Financial Regulator is adequately structured, funded, staffed, and provided with sufficient technical and other resources to fully and effectively perform their functions. They have sufficient operational independence and autonomy to ensure freedom from undue influence or interference.

32. The Central Bank Act (1997) also gives authorised officers of the Financial Regulator the power to enter premises and seize and review documents and require a regulated financial service provider to submit a compliance certificate certifying that it has complied with all relevant obligations. Between May 2003 and 31 December 2004 there were a total of 497 inspections and review meetings with banks, insurance companies, investment/stock broking firms, funds service providers and credit unions.

33. The Financial Regulator is obliged to report to the FIU and the Revenue Commissioners suspicions of ML or TF offences, or a breach of Irish AML/CFT requirements, by a regulated financial service provider. However the Financial Regulator has very limited powers to directly apply administrative sanctions for failure to comply ML or TF obligations, and at present is unable to use its general powers of sanction for specific breaches of the CJA (1994), though such breaches are liable to criminal prosecutions under the Act. Failure by a regulated financial service provider, or its management, to comply with a statutory demand of the Financial Regulator for information or to inspect records etc, or the provision of false or misleading information, would make it liable to supervisory action. Types of general supervisory actions can range from inspection letters requiring appropriate remedial action to the revocation of a licence/authorisation to carry on business. In addition the Financial Regulator has powers to impose a broad range of administrative sanctions, including fines, for breaches of designated supervisory enactments. However, the range of sanctions available specifically for AML/CFT breaches is limited to criminal prosecution and certain supervisory actions by the Financial Regulator such as issuing letters to financial service providers requiring action to be taken to rectify breaches of the AML/CFT regulations or revocation of a licence/authorisation. Ireland is reviewing its administrative sanctions for AML/CFT breaches in the context of the implementation of the $3^{\text {rd }}$ EU ML Directive. 
34. Money transmission businesses or services that operate in Ireland will be supervised and monitored by the Financial Regulator in the same way as bureaux de change and all AML/CFT obligations that are applicable to the other institutions are also applicable to the money remitters.

35. Overall, the evaluation team found that the AML/CFT requirements contained in the CJA (1994), combined with the sets of guidance notes, go some way towards meeting the FATF requirements but do not fully set out the necessary legally enforceable and sanctionable obligations relating to CDD and related preventive measures. This will need to be rectified by legislative and other changes. Further consideration could also be given to more fully incorporating a risk-based approach. The creation of the Financial Regulator has assisted in providing a consistent approach to AML/CFT supervision and regulation of financial institutions, and it is operating effectively, though it needs increased powers to sanction.

\section{Preventive Measures - Designated Non-Financial Businesses and Professions}

36. Most categories of DNFBPs operate in Ireland: real estate agents/auctioneers, dealers in precious metals and stones, solicitors and barristers, accountants and trust and company service providers. Ireland extends the same AML/CFT obligations for financial institutions to accountants, dealers in high value goods, solicitors and auctioneers and estate agents who are subject to the requirements of sections 31, 32, 57 and 59 of the CJA (1994). They are therefore subject to requirements to identity customers, keep records, have internal procedures to prevent and detect ML and TF and report STRs. Generally, the provisions lack effectiveness, since as noted above, the provisions impose limited requirements with respect to the application of CDD measures.

37. Trust and Company service providers are not covered by AML/CFT requirements as a separate DNFBP category despite the presence of specialist providers in Ireland. Casinos, including internet casinos, are illegal. However, it was noted that a number of private gaming clubs operate casino like facilities that create an AML/CFT risk, but which fall outside the scope of the CJA (1994). This lack of AML/CFT requirements for the trust and company service and gaming sectors was a matter of concern for the evaluation team.

38. Self-Regulatory Organisations (SRO) have assisted in the implementation of AML/CFT obligations for some of the DNFBP sectors, particularly in the production of sectoral guidance notes, though guidance regarding internal controls and the reporting of STRs is somewhat limited. Results achieved are also limited so far, with few STRs having been made by the DNFBP sector (less that $1 \%$ of all disclosures received in 2004).

39. Regulatory authorities and/or SROs have not been designated and empowered to apply sanctions for DNFBP's for non compliance with AML/CFT requirements and the bodies that do exist are not resourced to provide adequate oversight for AML/CFT compliance. Although breaches of $\mathrm{AML} / \mathrm{CFT}$ requirements can be reported to the Garda, which can undertake prosecution action if appropriate, the position is similar to that for financial institutions, since the range of possible sanctions is limited.

\section{$5 \quad$ Legal Persons and Arrangements \& Non-Profit Organisations}

40. A number of types of legal persons exist in Ireland; private companies, public companies, public companies limited by shares, credit unions, friendly societies and associations. The Office of the Director of Corporate Enforcement (ODCE) is responsible for enforcing compliance by companies and company officers with the requirements of the Companies Acts in Ireland. All companies and societies operating a business in Ireland are required to register with the Registrar of Companies or the 
Registrar of Friendly Societies. A list of shareholders is required to be registered annually with the Company Registration Office (CRO), and this data, together with other information, such as the directors, is made available to the public on the $\mathrm{CRO}$ website.

41. Individuals can obtain annual return information from the CRO for a small fee. This information will include the names and addresses of the directors and shareholders of the company. Any change in directorship must be notified to the CRO within 14 days, though the identity of directors is not verified. The law does not require disclosure to the CRO of beneficial ownership where the beneficial owner is a person other than the registered shareholder. Beneficial ownership information may be obtainable by use of police investigative powers, or through the appointment of an inspector under the Companies Act.

42. Ireland has a system of trust law that allows the creation of trusts. The settler, trustee or beneficiary under a trust is not recorded in any registry, nor do TCSPs hold any significant amount of information regarding trusts in Ireland. The Proceeds of Crime (Amendment) Act (2005) provides for application to the court for disclosure of the identity of persons for whom property is held in trust and under the Taxes Consolidation Act (1997) resident trustees can be obliged to give details of the name and address of every person in receipt of funds from the trust. Both for trusts and for companies, if the beneficial ownership or control structure is complicated then the details may be difficult to obtain and verify in a timely fashion. Ireland should broaden its requirements on beneficial ownership so that information on ownership/control is more readily available in a timely manner.

43. Ireland is in the process of reviewing its non-profit sector to ensure that there is appropriate oversight of the sector so it cannot be used to facilitate the financing of terrorism. Ireland should consider implementing specific measures from the Interpretative Note and Best Practices Paper to SR VIII or other appropriate measures.

\section{$6 \quad$ National and International Co-operation}

44. Procedures exist in Ireland to ensure that there is co-operation between relevant organisations at a national level. At a policy level Ireland is well represented within the EU structure and has been diligent in ensuring that EU directives are enforced. At an operational level Ireland participates within the EU framework and in a number of other recognised international fora including Europol, Interpol and the WCO. The evaluation team noted that departments and agencies co-operated as and when necessary, mostly through informal channels. The Money Laundering Steering Committee (MLSC) is the main structure for AML/CFT co-operation and co-ordination efforts providing a forum for national coordination and cooperation in relation to the development and implementation of policy and operational initiatives as well as for drafting and approving the sectoral guidance notes for financial institutions and DNFBPs.

45. Ireland has signed and ratified the Vienna Convention and signed the Palermo Convention, but has not yet ratified it, although the majority of its provisions are already implemented for AML purposes. The 1999 UN International Convention for the Suppression of the Financing of Terrorism has been signed, ratified and implemented.

46. Ireland is also party to a number of multilateral conventions containing provisions for Mutual Legal Assistance (MLA), including the Council of Europe Convention on Mutual Assistance in Criminal Matters 1957, and the Council of Europe Convention on Laundering, Search, Seizure and Confiscation of the Proceeds of Crime 1990.

47. Mechanisms have been put in place to ensure that Ireland can co-operate internationally and it has negotiated a number of MOUs. Bilateral MLA agreements have also been concluded with United Kingdom; Hong Kong, China; and the United States of America. A proactive approach to negotiating mechanisms for international co-operation should continue. 
48. International assistance does not appear to be prohibited or subject to unreasonable, disproportionate or unduly restrictive conditions. The implementation of the Recommendations concerning MLA appears to be working adequately in practice. Ireland has the basic legal mechanisms in place to facilitate requests. The majority of mutual assistance provisions require the establishment of dual criminality. In 2004, 106 requests for MLA were received. For the purposes of enforcing foreign confiscation orders, the provisions of the CJA (1994) apply as if the order were a domestic confiscation order.

49. Ireland has the ability to extradite for ML and TF under Extradition Acts 1965 to 2001 and has concluded bilateral extradition treaties with Australia and the United States of America which have also been applied under Part II of the 1965 Act. For EU states Ireland can utilise the procedures in the European Arrest Warrant allowing the efficient processing of extradition actions between member states without the requirement for dual criminality for certain types of offences, including ML and TF.

50. Other forms of co-operation are available to Irish authorities through the FIU, law enforcement to law enforcement and regulator to regulator channels. In 2004, 209 inquiries were made through the Egmont group. In general, these channels of co-operation appear to be operating effectively.

\begin{tabular}{|c|c|c|}
\hline Forty Recommendations & 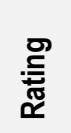 & Summary of factors underlying rating ${ }^{2}$ \\
\hline \multicolumn{3}{|l|}{ Legal systems } \\
\hline 1. ML offence & LC & - The number of prosecutions and convictions are low. \\
\hline $\begin{array}{l}\text { 2. ML offence - mental element } \\
\text { and corporate liability }\end{array}$ & LC & $\begin{array}{l}\text { - The regime for sanctions appears comprehensive, dissuasive } \\
\text { and proportional; however the number of prosecutions and } \\
\text { convictions are low. }\end{array}$ \\
\hline $\begin{array}{ll}\text { 3. } & \begin{array}{l}\text { Confiscation and provisional } \\
\text { measures }\end{array} \\
\end{array}$ & C & This Recommendation is fully met \\
\hline \multicolumn{3}{|l|}{ Preventive measures } \\
\hline $\begin{array}{ll}\text { 4. Secrecy laws consistent with the } \\
\text { Recommendations }\end{array}$ & C & The Recommendation is fully met. \\
\hline 5. $\quad$ Customer due diligence & $\mathrm{PC}$ & $\begin{array}{l}\text { - Financial institutions are not currently required to undertake full } \\
\text { CDD measures on establishing business relations, when } \\
\text { carrying out occasional transactions over } € 13,000 \text { or in } \\
\text { circumstances in relation to SRVII and there is no requirement } \\
\text { to identify in cases where TF is suspected. } \\
\text { - A number of requirements which should be explicitly set out in } \\
\text { law or regulation are now currently implicit or established only } \\
\text { in guidance. For example: } \\
\text { - ongoing due diligence; } \\
\text { o identification of the beneficial ownership of legal persons; } \\
\text { Certain requirements such as obtaining information on the } \\
\text { nature and purpose of the business relationship and timing of } \\
\text { verification requirements are not required by "other enforceable } \\
\text { means" (as defined by the FATF) } \\
\text { There is no legally binding provision for enhanced CDD } \\
\text { measures and guidance is weak on the requirements } \\
\text { concerning consequences of failure to complete CDD. } \\
\text { In the context of a future risk-based approach there should be a } \\
\text { review of the documents and data that is relied upon for } \\
\text { customer identification and verification. }\end{array}$ \\
\hline
\end{tabular}

\footnotetext{
${ }^{2}$ These factors are only required to be set out when the rating is less than Compliant.
} 


\begin{tabular}{|c|c|c|}
\hline & & $\begin{array}{l}\text { - Provisions addressing identification of existing customers are } \\
\text { limited to cases to where ML is suspected. }\end{array}$ \\
\hline $\begin{array}{ll}6 . & \text { Politically exposed persons }\end{array}$ & $\mathrm{NC}$ & $\begin{array}{l}\text { - There are no legislative or other enforceable obligations } \\
\text { currently in force. }\end{array}$ \\
\hline 7. $\quad$ Correspondent banking & NC & $\begin{array}{l}\text { - There are no legislative or other enforceable obligations } \\
\text { currently in force. }\end{array}$ \\
\hline $\begin{array}{l}\text { 8. New technologies \& non face-to- } \\
\text { face business }\end{array}$ & PC & $\begin{array}{l}\text { - Limited measures have been taken in guidance for non -face- } \\
\text { to-face business and new technologies. }\end{array}$ \\
\hline 9. Third parties and introducers & NC & $\begin{array}{l}\text { - No legally binding obligations are currently in force governing } \\
\text { identification carried out by third parties or introducers on behalf } \\
\text { of designated bodies. }\end{array}$ \\
\hline 10. Record keeping & C & The Recommendation is fully met \\
\hline 11. Unusual transactions & PC & $\begin{array}{l}\text { - There is no explicit requirement to pay attention to all unusual, } \\
\text { complex large transactions and transactions with no visible } \\
\text { economic purposes, nor to further examine these situations and } \\
\text { to set out these findings in writing. }\end{array}$ \\
\hline 12. DNFBP - R.5, 6, 8-11 & PC & $\begin{array}{l}\text { - Not all DNFBPs are obliged to undertake CDD and record } \\
\text { keeping for AML/CFT purposes as covered by the } \\
\text { Recommendation } 12 \text {. } \\
\text { The same deficiencies apply for DNFBPs as for financial } \\
\text { institutions in the implementation of Recommendation } 5 \\
\text { regarding CDD, including the consequences of failure to } \\
\text { complete CDD, timing of verification requirements and } \\
\text { provisions addressing identification of existing customers. } \\
\text { - Under the present regime there are no, or limited requirements } \\
\text { to apply higher risk measures as required under } \\
\text { Recommendations } 6,8 \text { and } 9 \text {. } \\
\text { Guidance is limited in relation to the DNFBPs obligations to pay } \\
\text { attention to complex and unusual transactions (applying } \\
\text { Recommendation 11). } \\
\text { A proportionate range of sanctions are not directly available for } \\
\text { AML/CFT failures and not all DNFBPs have a designated body } \\
\text { (supervisor or SRO) to impose AML/CFT sanctions (applying } \\
\text { Recommendation 17). }\end{array}$ \\
\hline 13. Suspicious transaction reporting & C & This Recommendation is fully met. \\
\hline 14. Protection \& no tipping-off & $C$ & This Recommendation is fully met. \\
\hline $\begin{array}{l}\text { 15. Internal controls, compliance \& } \\
\text { audit }\end{array}$ & LC & $\begin{array}{l}\text { - There are no legislative or other enforceable obligations to } \\
\text { ensure that appropriate compliance management arrangements } \\
\text { are in place, that compliance staffs have timely access to CDD } \\
\text { and transaction information and that require screening } \\
\text { procedures for hiring employees. }\end{array}$ \\
\hline 16. DNFBP - R.13-15 \& 21 & PC & $\begin{array}{l}\text { - Not all DNFBPs are subject to the STR obligations. } \\
\text { DNFBPs are not required to develop internal policies } \\
\text { procedures, internal controls, ongoing employee training and } \\
\text { compliance in respect of AML/CFT. } \\
\text { - There are not adequate measures for DNFBPs to pay special } \\
\text { attention to transactions involving certain countries and to make } \\
\text { their findings available in writing, or apply appropriate counter- } \\
\text { measures. } \\
\text { - The STR regime is not yet effective with low numbers of STRs } \\
\text { being made by DNFBPs. } \\
\text { A proportionate range of sanctions are not available for } \\
\text { AML/CFT failures and not all DNFBPs have a designated body } \\
\text { (supervisor or SRO) to impose AML/CFT sanctions (applying } \\
\text { Recommendation 17). }\end{array}$ \\
\hline 17. Sanctions & PC & $\begin{array}{l}\text { - This recommendation is overall not effectively implemented as } \\
\text { there is no range of sanctions available proportionate to the } \\
\text { severity of a situation. }\end{array}$ \\
\hline
\end{tabular}




\begin{tabular}{|c|c|c|}
\hline & & $\begin{array}{l}\text { - Administrative sanctions are not yet directly available for } \\
\text { AML/CFT purposes. }\end{array}$ \\
\hline 18. Shell banks & $P C$ & $\begin{array}{l}\text { - Correspondent banking relationships with shell banks are not } \\
\text { forbidden by law or regulation. } \\
\text { - There is no prohibition on financial institutions from entering } \\
\text { into, or continuing correspondent banking relationships with } \\
\text { shell banks. } \\
\text { - Financial Institutions are not required to satisfy themselves that } \\
\text { respondent institutions in a foreign country do not permit } \\
\text { accounts to be used by shell banks. }\end{array}$ \\
\hline 19. Other forms of reporting & C & The Recommendation is fully met \\
\hline $\begin{array}{l}\text { 20. Other NFBP \& secure } \\
\text { transaction techniques }\end{array}$ & C & The Recommendation is fully met \\
\hline $\begin{array}{l}\text { 21. Special attention for higher risk } \\
\text { countries }\end{array}$ & PC & $\begin{array}{l}\text { - There is no mechanism in place to make designated bodies } \\
\text { aware of weaknesses in other countries' AML/CFT systems. } \\
\text { - There is no requirement to examine and monitor transactions } \\
\text { from countries who insufficiently apply FATF Recommendations } \\
\text { that have no apparent economic or lawful purpose, or to make } \\
\text { these findings available to competent authorities. }\end{array}$ \\
\hline 22. Foreign branches \& subsidiaries & LC & $\begin{array}{l}\text { - Some of the requirements of this Recommendation are in } \\
\text { guidance. The requirement for financial institutions to ensure } \\
\text { that foreign branches and subsidiaries comply with FATF } \\
\text { standards is mentioned very briefly in guidance. Legislation } \\
\text { allows the exchanging of information when a supervisor may } \\
\text { observe that a branch or subsidiary is unable to observe } \\
\text { AML/CFT standards. } \\
\text { There are no legislative or other enforceable obligations to } \\
\text { ensure that financial institutions should be required to pay } \\
\text { particular attention to branches and subsidiaries in countries } \\
\text { that insufficiently do not apply FATF Recommendations, nor } \\
\text { that the higher standard of AML/CFT obligations should apply - } \\
\text { although in practice this may be applied through group policies. }\end{array}$ \\
\hline $\begin{array}{l}\text { 23. Regulation, supervision and } \\
\text { monitoring }\end{array}$ & LC & $\begin{array}{l}\text { - The Financial Regulator has a full range of supervisory powers } \\
\text { to adequately regulate and supervise for AML/CFT matters. A } \\
\text { fully implemented compliance regime for money transmission } \\
\text { services is not yet in effect, the initial steps are being taken } \\
\text { through licensing of these entities. }\end{array}$ \\
\hline $\begin{array}{l}\text { 24. DNFBP - regulation, supervision } \\
\text { and monitoring }\end{array}$ & $\mathrm{NC}$ & $\begin{array}{l}\text { - Almost all DNFBPs are not subject to oversight for AML/CFT } \\
\text { purposes. } \\
\text { - Where an oversight role exists the SROs do not have sufficient } \\
\text { resources to perform these functions. }\end{array}$ \\
\hline 25. Guidelines \& Feedback & LC & $\begin{array}{l}\text { - Sectoral guidance notes are provided to financial institutions } \\
\text { providing direction in the application of the AML/CFT legislation. } \\
\text { While this is generally quite comprehensive these should be } \\
\text { enhanced to include requirements to conduct ongoing CDD and } \\
\text { pay particular attention to high risk business relationships as } \\
\text { indicated in Recommendations } 5-9,11 \text { and } 21 \\
\text { - General feedback could be improved by co-operation between } \\
\text { the FIU and the Revenue Commissioners so as to enhance the } \\
\text { provision of information on current methods, trends and } \\
\text { techniques. } \\
\text { Guidance is given to some DNFBP's, but others are not } \\
\text { covered. } \\
\text { The guidance provided to DNFBP's covered is not always } \\
\text { sufficiently detailed. }\end{array}$ \\
\hline \multicolumn{3}{|l|}{ Institutional and other measures } \\
\hline 26. The FIU & LC & $\begin{array}{l}\text { - The FIU as a whole meets most of the individual requirements } \\
\text { of the FATF methodology. However, its ability to operate } \\
\text { effectively is limited by resources available to do a number of }\end{array}$ \\
\hline
\end{tabular}




\begin{tabular}{|c|c|c|}
\hline & & $\begin{array}{l}\text { important tasks: to encourage quality STRs from designated } \\
\text { bodies, research and develop intelligence for ML and TF } \\
\text { investigations from STR information and provide management } \\
\text { information to assist the overall AML/CFT effort. The role and } \\
\text { effectiveness of the FIU is therefore limited. } \\
\text { The FIU does not release periodic reports or conduct strategic } \\
\text { analysis. }\end{array}$ \\
\hline 27. Law enforcement authorities & C & Recommendation is fully met \\
\hline 28. Powers of competent authorities & $\mathrm{C}$ & Recommendation is fully met \\
\hline 29. Supervisors & LC & $\begin{array}{l}\text { - The Financial Regulator is unable to directly apply a range of } \\
\text { administrative sanctions for AML/CFT breaches. }\end{array}$ \\
\hline 30. Resources, integrity and training & LC & $\begin{array}{l}\text { - Resources available to sanction, supervise and issue } \\
\text { guidelines are good and those available to investigate ML and } \\
\text { TF and to examine integrity of law enforcement agencies on the } \\
\text { whole appear adequate. Resources for the MLIU to conduct a } \\
\text { comprehensive role as the FIU, to develop STR information and } \\
\text { conduct initial investigations are limited. }\end{array}$ \\
\hline 31. National co-operation & LC & $\begin{array}{l}\text { - A lack of formal AML/CFT framework outside the issuance of } \\
\text { guidance notes limits the targeting of the resources that Ireland } \\
\text { has directed at AML/CFT systems. There is room for more } \\
\text { formal increased interagency co-operation particularly between } \\
\text { the MLIU and the Financial Regulator. }\end{array}$ \\
\hline 32. Statistics & PC & $\begin{array}{l}\text { - Overall there are a limited number of statistics are available to } \\
\text { assess the effectiveness of the AML/CFT regime. } \\
\text { The available statistics are not used for systematic review of } \\
\text { the effectiveness and efficiency of AML/CFT systems. } \\
\text { - There is no overall proactive review of the AML/CFT } \\
\text { effectiveness. }\end{array}$ \\
\hline $\begin{array}{l}\text { 33. Legal persons - beneficial } \\
\text { owners }\end{array}$ & PC & $\begin{array}{l}\text { - Competent authorities do not have access in a timely fashion to } \\
\text { adequate, accurate and current information on beneficial } \\
\text { ownership and control. }\end{array}$ \\
\hline $\begin{array}{l}\text { 34. Legal arrangements - beneficial } \\
\text { owners }\end{array}$ & PC & $\begin{array}{l}\text { - Competent authorities have limited powers to have timely } \\
\text { access to information on the beneficial ownership and control of } \\
\text { trusts. }\end{array}$ \\
\hline \multicolumn{3}{|l|}{ International Co-operation } \\
\hline 35. Conventions & LC & $\begin{array}{l}\text { - The Vienna Convention and TF Convention have been signed, } \\
\text { ratified and implemented. The Palermo Convention has been } \\
\text { signed but not yet ratified, although almost all of the provisions } \\
\text { are already implemented for ML purposes. }\end{array}$ \\
\hline 36. Mutual legal assistance (MLA) & $\mathrm{C}$ & The Recommendation is fully met \\
\hline 37. Dual criminality & $C$ & The Recommendation is fully met \\
\hline $\begin{array}{l}\text { 38. MLA on confiscation and } \\
\text { freezing }\end{array}$ & C & The Recommendation is fully met \\
\hline 39. Extradition & C & The Recommendation is fully met \\
\hline 40. Other forms of co-operation & $C$ & The Recommendation is fully met \\
\hline \multicolumn{3}{|l|}{ Nine Special Recommendations } \\
\hline SR.I Implement UN instruments & PC & $\begin{array}{l}\text { - S/RES/ } 1267 \text { has been implemented but S/RES/1373 (2001) } \\
\text { has not been adequately implemented. In particular, no } \\
\text { mechanisms exist for the immediate freezing of funds of } \\
\text { designated terrorists outside the EU listing mechanism. } \\
\text { - There is no system for effectively communicating action taken } \\
\text { by the authorities under the freezing mechanisms to designated } \\
\text { non-financial business and professions. } \\
\text { Designated non-financial businesses and professions are not } \\
\text { adequately monitored for compliance with measures taken } \\
\text { under the Resolutions. }\end{array}$ \\
\hline
\end{tabular}




\begin{tabular}{|c|c|c|}
\hline SR.II Criminalise TF & LC & $\begin{array}{l}\text { - The TF offence does not extend to the provision or collection of } \\
\text { funds for the benefit of a group of less than three terrorists } \\
\text { including a single terrorist (except where the funds are provided } \\
\text { for use, in whole or in part, in order to carry out a terrorist act), } \\
\text { due to the use and definition of the term "terrorist group" in the } \\
\text { legislation. } \\
\text { It is too early to assess the effective implementation of the TF } \\
\text { offence provisions, because they have only been operative } \\
\text { since March } 82005 \text {. }\end{array}$ \\
\hline $\begin{array}{l}\text { SR.III Freeze and confiscate terrorist } \\
\text { assets }\end{array}$ & PC & $\begin{array}{l}\text { - Ireland has limited ability to freeze funds in accordance with } \\
\text { S/RES/1373 (2001) of designated terrorists outside the EU } \\
\text { listing system. } \\
\text { - Ireland does not effectively communicate measures taken } \\
\text { under freezing mechanisms to DNFBPs. } \\
\text { - Ireland does not adequately monitor DNFBPs for compliance } \\
\text { with the relevant laws for freezing of terrorist funds, } \\
\text { notwithstanding the existence of criminal penalties for non- } \\
\text { compliance. }\end{array}$ \\
\hline SR.IV Suspicious transaction reporting & C & The Recommendation is fully met \\
\hline SR.V International co-operation & $\mathrm{C}$ & The Recommendation is fully met. \\
\hline $\begin{array}{l}\text { SR VI AML requirements for } \\
\text { money/value transfer } \\
\text { services }\end{array}$ & PC & $\begin{array}{l}\text { - As with other financial institutions, overall implementation of } \\
\text { Recommendations } 5-10,15,17,21,22 \text { and Special } \\
\text { Recommendation VII is inadequate, this negatively impacts on } \\
\text { the effectiveness of AML/CFT measures for money } \\
\text { transmission services. }\end{array}$ \\
\hline SR VII Wire transfer rules & NC & $\begin{array}{l}\text { - The requirements for transfers to record include and maintain } \\
\text { originator information is limited and currently only contained in } \\
\text { guidance } \\
\text { There is no obligation to verify that the originator information is } \\
\text { accurate and meaningful. } \\
\text { - There are no obligations to require financial institutions to apply } \\
\text { risk-based procedures when originator information is } \\
\text { incomplete. }\end{array}$ \\
\hline SR.VIII Non-profit organisations & PC & $\begin{array}{l}\text { - Ireland is in the process of completing a review of its NPO } \\
\text { sector, but has not yet implemented measures to ensure } \\
\text { accountability and transparency in the sector so that terrorist } \\
\text { organisations cannot pose as legitimate non profit } \\
\text { organisations, or to ensure that funds/assets collected by or } \\
\text { transferred through non-profit organisations are not diverted to } \\
\text { support the activities of terrorists or terrorist organisations. }\end{array}$ \\
\hline SR. IX & PC & $\begin{array}{l}\text { - There are no powers to obtain a truthful disclosure upon } \\
\text { request by individuals suspected of physical cross-border } \\
\text { transportation of cash or bearer negotiable instruments. } \\
\text { - } \quad \text { No sanctions are available for false declarations/ disclosure. } \\
\text { - Measures are not currently in place to fully comply with SR IX. }\end{array}$ \\
\hline
\end{tabular}


Table 2: Recommended Action Plan to Improve the AML/CFT System

\begin{tabular}{|c|c|}
\hline AML/CFT System & Recommended Action (listed in order of priority) \\
\hline \multicolumn{2}{|l|}{ 1. General } \\
\hline \multicolumn{2}{|l|}{$\begin{array}{l}\text { 2. Legal System and Related } \\
\text { Institutional Measures }\end{array}$} \\
\hline Criminalisation of ML (R.1 \& 2) & $\begin{array}{l}\text { - Criminalise the participation in an organised criminal group. } \\
\text { Improve the implementation of the ML offence, providing } \\
\text { the necessary incentives to investigators and prosecutors to } \\
\text { prosecute ML cases as separate and serious offences. } \\
\text { - Ascertain why the number of ML cases remains low. }\end{array}$ \\
\hline Criminalisation of TF (SR.II) & $\begin{array}{l}\text { - Criminalise the collection or provision of funds for an } \\
\text { individual terrorist. }\end{array}$ \\
\hline $\begin{array}{l}\text { Confiscation, freezing and seizing of } \\
\text { proceeds of crime (R.3) }\end{array}$ & $\begin{array}{l}\text { - Consider extending civil forfeiture for all instrumentalities of } \\
\text { crime. } \\
\text { The Irish authorities should collect statistics on the number of } \\
\text { cases and the amount assets seized in relation to criminal } \\
\text { confiscation. }\end{array}$ \\
\hline $\begin{array}{l}\text { Freezing of funds used for TF } \\
\text { (SR.III) }\end{array}$ & $\begin{array}{l}\text { - Ireland should extend its current limited ability to freeze } \\
\text { funds in accordance with } \mathrm{S} / \mathrm{RES} / 1373 \text { and ensure that all } \\
\text { freezing actions are communicated to relevant DNFBPs. } \\
\text { There should be adequate monitoring of DNFBPs to ensure } \\
\text { they comply with required freezing actions. }\end{array}$ \\
\hline $\begin{array}{l}\text { The Financial Intelligence Unit and } \\
\text { its functions (R.26, } 30 \text { \& 32) }\end{array}$ & $\begin{array}{l}\text { - It is recommended that Ireland allocate more resources (both } \\
\text { staff and technical resources. Although the current staff are } \\
\text { professional and highly trained the FIU would benefit from } \\
\text { increased numbers to conduct the large number of tasks } \\
\text { expected of the unit. A system of electronic reporting would } \\
\text { assist manage the increasing number of STRs being received. } \\
\text { The FIU is encouraged to establish a team of financial } \\
\text { analysts to ensure that STR information is thoroughly } \\
\text { analysed. } \\
\text { The FIU should seek and encourage regular feedback from } \\
\text { partner agencies on the quality of the information / } \\
\text { intelligence provided and the overall level of service of the } \\
\text { FIU; in addition the benefits and results derived from FIU } \\
\text { information should be fed back to the FIU. } \\
\text { Ireland could improve the FIU statistics and case } \\
\text { management statistics by improving technological resources. } \\
\text { In consultation with partner agencies, the FIU should } \\
\text { consider how information / results can optimally be shared } \\
\text { with reporting entities. } \\
\text { The FIU should continue to proactively negotiate MOUs with } \\
\text { foreign FIUs }\end{array}$ \\
\hline $\begin{array}{l}\text { Law enforcement, prosecution and } \\
\text { other competent authorities (R.27, } \\
28,30 \& 32 \text { ) }\end{array}$ & $\begin{array}{l}\text { - Investigative and prosecutorial authorities need to focus more } \\
\text { on investigating and prosecuting ML offences. Irish } \\
\text { authorities are encouraged to make this an objective. } \\
\text { There is a need for Irish authorities to keep clearer statistics } \\
\text { on investigations and prosecutions of the ML offence. }\end{array}$ \\
\hline
\end{tabular}




\begin{tabular}{|c|c|}
\hline & $\begin{array}{l}\text { Irish authorities should consider the utility of establishing } \\
\text { and AML working group with relevant government and } \\
\text { investigation agencies to regularly discuss issues of common } \\
\text { interest such as statistic gathering and to develop approaches } \\
\text { for dealing with emerging issues. } \\
\text { Ireland should collect statistics concerned the types of } \\
\text { criminal sanctions imposed for ML under Sections } 31 \text { and } 32 \\
\text { of the CJA (1994) (as amended). }\end{array}$ \\
\hline \multicolumn{2}{|l|}{$\begin{array}{l}\text { 3. Preventive Measures - } \\
\text { Financial Institutions }\end{array}$} \\
\hline \multicolumn{2}{|l|}{ Risk of ML or TF } \\
\hline $\begin{array}{l}\text { Customer due diligence, including } \\
\text { enhanced or reduced measures (R.5 } \\
\text { to } 8 \text { ) }\end{array}$ & $\begin{array}{l}\text { - Financial institutions should be required to apply CDD } \\
\text { requirements to existing customers on the basis of materiality } \\
\text { and risk. } \\
\text { - Ireland needs to require financial institutions to identify } \\
\text { occasional customers as contemplated in SR VII for domestic } \\
\text { transfers and in the cases where there is a suspicion of TF. } \\
\text { Financial institutions should be required to obtain } \\
\text { information on the purpose and intended business nature of } \\
\text { the business relationship, conduct ongoing due diligence of } \\
\text { the business relationship, and keep CDD data up-to-date. } \\
\text { In the cases where adequate CDD data is not obtained, } \\
\text { financial institutions should be required to consider filing an } \\
\text { STR. } \\
\text { Adopt requirements for financial institutions to perform } \\
\text { enhanced due diligence for higher risk categories of } \\
\text { customer, business relationships and transactions. } \\
\text { Adopt requirements for PEPs as contemplated in } \\
\text { Recommendation } 6 \text { and measures for correspondent } \\
\text { relationships as contemplated in Recommendation } 7 \text {. } \\
\text { Require financial institutions to have policies in place or take } \\
\text { measures necessary to prevent the misuse of technological } \\
\text { developments in ML and TF. } \\
\text { Adopt legally binding provision requiring financial } \\
\text { institutions to make enquiries for the beneficial owner(s) of } \\
\text { corporate customers. }\end{array}$ \\
\hline $\begin{array}{l}\text { Third parties and introduced } \\
\text { business (R.9) }\end{array}$ & $\begin{array}{l}\text { Ensure that legally enforceable regulations or guidelines } \\
\text { establishing obligations so that financial institutions can } \\
\text { obtain relevant customer identification and verification } \\
\text { information in a timely manner. }\end{array}$ \\
\hline \multicolumn{2}{|l|}{$\begin{array}{l}\text { Financial institution secrecy or } \\
\text { confidentiality (R.4) }\end{array}$} \\
\hline $\begin{array}{l}\text { Record keeping and wire transfer } \\
\text { rules (R.10 \& SR.VII) }\end{array}$ & $\begin{array}{l}\text { - SR VII has not been implemented in most respects. Ireland } \\
\text { should implement the provisions of SR VII as soon as } \\
\text { possible. }\end{array}$ \\
\hline $\begin{array}{l}\text { Monitoring of transactions and } \\
\text { relationships (R.11\& 21) }\end{array}$ & $\begin{array}{l}\text { - Adopt regulations or guidelines that are subject to sanctions } \\
\text { for persons that fail to comply with there obligations } \\
\text { establishing an explicit obligation for all financial institutions } \\
\text { to perform the requisites required by Recommendation } 11 \text {. } \\
\text { Ensure that enforceable regulations or guidelines are clear on } \\
\text { the obligations of Recommendation } 21 \text {. }\end{array}$ \\
\hline $\begin{array}{l}\text { Suspicious transaction reports and } \\
\text { other reporting (R.13-14, 19, 25 \& }\end{array}$ & $\begin{array}{l}\text { - Expand the definition of the TF offence to include the } \\
\text { provision/collection of funds for an individual terrorist so as }\end{array}$ \\
\hline
\end{tabular}




\begin{tabular}{|c|c|}
\hline SR.IV) & $\begin{array}{l}\text { to ensure that transactions related to these activities are } \\
\text { reportable. }\end{array}$ \\
\hline $\begin{array}{l}\text { Cross-border declaration or } \\
\text { disclosure (SR.IX) }\end{array}$ & - $\quad$ Ireland should implement SR IX without restriction. \\
\hline $\begin{array}{l}\text { Internal controls, compliance, audit } \\
\text { and foreign branches (R.15 \& 22) }\end{array}$ & $\begin{array}{l}\text { - Introduce enforceable obligations to ensure that compliance } \\
\text { staff has timely access to CDD and transaction information } \\
\text { and that require screening procedures for hiring employees. } \\
\text { Require financial institutions to pay particular attention that } \\
\text { the principle is observed to branches and subsidiaries in } \\
\text { countries that insufficiently apply FATF Recommendations. }\end{array}$ \\
\hline Shell banks (R.18) & $\begin{array}{l}\text { Prohibit financial institutions from entering into, or } \\
\text { continuing, correspondent banking relationships with shell } \\
\text { banks and require financial institutions to satisfy themselves } \\
\text { that respondent institutions in a foreign country do no permit } \\
\text { their account to be used by shell banks. }\end{array}$ \\
\hline $\begin{array}{l}\text { The supervisory and oversight } \\
\text { system - competent authorities and } \\
\text { SROs } \\
\text { Role, functions, duties and powers } \\
\text { (including sanctions) } \\
\text { (R. 23, 30, 29, 17, 32, \& 25). }\end{array}$ & $\begin{array}{l}\text { - Consider introducing an administrative penalties regime that } \\
\text { can be imposed on regulated entities and persons who are } \\
\text { non-compliant under section } 32 \text { and } 57 \text { of the CJA (1994) (as } \\
\text { amended) Act. } \\
\text { - Ireland should maintain statistics concerning the number and } \\
\text { type of sanctions applied. } \\
\text { Enhanced existing sectoral AML guidance to include } \\
\text { requirements to conduct ongoing CDD and pay particular } \\
\text { attention to high risk business relationships as indicated in } \\
\text { Recommendations 5-9,11 and } 21 \text {. }\end{array}$ \\
\hline $\begin{array}{l}\text { Money value transfer services } \\
\text { (SR.VI) }\end{array}$ & $\begin{array}{l}\text { Ireland should continue its intended supervision of money } \\
\text { value transfer systems, implementing an effective licensing } \\
\text { regime. }\end{array}$ \\
\hline $\begin{array}{l}\text { 4. Preventive Measures -Non- } \\
\text { Financial Businesses and } \\
\text { Professions }\end{array}$ & \\
\hline $\begin{array}{l}\text { Customer due diligence and record- } \\
\text { keeping (R.12) }\end{array}$ & $\begin{array}{l}\text { - Ireland should implement Recommendation } 5 \text { and } 6 \text { fully. } \\
\text { - Ireland should bring in legislative changes to ensure that all } \\
\text { DNFBPs have adequate CDD and record keeping obligations } \\
\text { in situations required by Recommendation } 12 \text {. } \\
\text { Ireland should be aware of the ML issues relating to the illicit } \\
\text { operation of casinos and should be prepared to address these } \\
\text { problems. } \\
\text { DNFBPs should be required to establish and maintain } \\
\text { internal procedures, policies and controls to prevent ML and } \\
\text { TF, and to communicate these to their employees. These } \\
\text { procedures, policies and controls should cover: CDD and the } \\
\text { detection of unusual and suspicious transactions and the } \\
\text { reporting obligation. DNFBPs should be required to } \\
\text { maintain an independent audit function and establish ongoing } \\
\text { employee training. }\end{array}$ \\
\hline $\begin{array}{l}\text { Monitoring of transactions and } \\
\text { relationships (R.12 \& 16) }\end{array}$ & $\begin{array}{l}\text { - Ireland should compel DNFBPs to pay special attention to } \\
\text { transactions involving certain countries make their findings } \\
\text { available in writing, and apply appropriate countermeasures. }\end{array}$ \\
\hline $\begin{array}{l}\text { Suspicious transaction reporting } \\
\text { (R.16) }\end{array}$ & $\begin{array}{l}\text { - Ensure that all DNFBPs are covered by the reporting } \\
\text { obligation. }\end{array}$ \\
\hline Internal controls, compliance \& & - $\quad$ Ensure that DNFBPs are required to develop internal \\
\hline
\end{tabular}




\begin{tabular}{|c|c|}
\hline audit (R.16) & $\begin{array}{l}\text { policies, procedures, controls and ongoing employee training } \\
\text { with regard to AML/CFT and that sanctions can be applied in } \\
\text { the event of and AML/CFT breach. }\end{array}$ \\
\hline $\begin{array}{l}\text { Regulation, supervision and } \\
\text { monitoring (R.17, 24-25) }\end{array}$ & $\begin{array}{l}\text { - The scope of the CJA (1994) (as amended) Act needs to be } \\
\text { extended so as to bring all types of DBFBP under the } \\
\text { AML/CFT regime. } \\
\text { Ireland should be aware of the ML issues relating to the illicit } \\
\text { operation of casinos and should be prepared to address these } \\
\text { problems. } \\
\text { DNFBPs should be required to establish and maintain } \\
\text { internal procedures, policies and controls to prevent ML and } \\
\text { TF, and to communicate these to their employers. These } \\
\text { procedures, policies and controls should cover: CDD and the } \\
\text { detection of unusual and suspicious transactions and the } \\
\text { reporting obligation.. DNFBPs should be required to } \\
\text { maintain an independent audit function and establish ongoing } \\
\text { employee training. } \\
\text { Ireland should introduce administrative sanctions for } \\
\text { breaches of AML/CFT requirements by DNFBPs. } \\
\text { The scope and coverage of reporting entities should be } \\
\text { enhanced to include all DNFBPs. The Irish Authorities } \\
\text { should designate Supervisors or enabling the financial } \\
\text { regulator or SROs to regulate and supervise all categories for } \\
\text { AML/CFT. } \\
\text { Competent authorities should establish guidelines that would } \\
\text { cover the full range of DNFBPs a assist them to implement } \\
\text { and comply with their respective AML/CFT requirements } \\
\text { Appropriate sanctions should be adopted for non-compliance, } \\
\text { including a regime of administrative sanctions. }\end{array}$ \\
\hline $\begin{array}{l}\text { Other designated non-financial } \\
\text { businesses and professions (R.20) }\end{array}$ & \\
\hline $\begin{array}{l}\text { 5. Legal Persons and } \\
\text { Arrangements \& Non-Profit } \\
\text { Organisations }\end{array}$ & \\
\hline $\begin{array}{l}\text { Legal Persons - Access to beneficial } \\
\text { ownership and control information } \\
\text { (R.33) }\end{array}$ & $\begin{array}{l}\text { - Ireland should take additional measures to ensure that } \\
\text { information concerning beneficial ownership is available on a } \\
\text { timelier basis. }\end{array}$ \\
\hline $\begin{array}{l}\text { Legal Arrangements - Access to } \\
\text { beneficial ownership and control } \\
\text { information (R.34) }\end{array}$ & $\begin{array}{l}\text { - Ireland should take additional measures to ensure that } \\
\text { competent authorities have timelier access to beneficial } \\
\text { ownership and control of trusts. }\end{array}$ \\
\hline Non-profit organisations (SR.VIII) & $\begin{array}{l}\text { Ireland should continue to review the adequacy of laws and } \\
\text { regulations in place to ensure that terrorist organisations } \\
\text { cannot pose as legitimate non-profit organisations. } \\
\text { Ireland should give consideration to implementing specific } \\
\text { measures from the BPP for SR VIII to other measures to } \\
\text { ensure that funds or other assets collected or transferred } \\
\text { through non-profit organisations are not diverted to support } \\
\text { terrorist organisations. }\end{array}$ \\
\hline $\begin{array}{l}\text { 6. National and International } \\
\text { Co-operation }\end{array}$ & \\
\hline $\begin{array}{l}\text { National co-operation and } \\
\text { coordination (R.31) }\end{array}$ & $\begin{array}{l}\text { - Ireland should ensure that all existing co-operation } \\
\text { mechanisms are functioning effectively. }\end{array}$ \\
\hline
\end{tabular}




\begin{tabular}{|c|c|}
\hline & $\begin{array}{l}\text { Improve the level of co-operation and co-ordination between } \\
\text { the FIU and the financial regulator, and also to enhance co- } \\
\text { ordination at the policy level, possibly through the } \\
\text { establishment of a formal national co-ordination mechanism }\end{array}$ \\
\hline $\begin{array}{l}\text { The Conventions and UN Special } \\
\text { Resolutions (R.35 \& SR.I) }\end{array}$ & $\begin{array}{l}\text { - Ratify the Palermo convention and ensure that S/RES/1373 } \\
\text { (2001) is fully implemented. } \\
\text { - Ensure that DNFBP's are advised of their obligations under } \\
\text { S/RES/1267 (1999) and S/RES/1373 (2001). }\end{array}$ \\
\hline $\begin{array}{l}\text { Mutual Legal Assistance (R.32, 36- } \\
\text { 38, SR.V) }\end{array}$ & $\begin{array}{l}\text { Specifically criminalise the provision / collection of funds } \\
\text { involving a single terrorist, to ensure that the discretionary } \\
\text { grounds of dual criminality are not used in the future to } \\
\text { refuse legal assistance requests. }\end{array}$ \\
\hline Extradition (R.32, $37 \& 39, \&$ SR.V) & $\begin{array}{l}\text { - Specifically criminalise the provision / collection of funds } \\
\text { involving a single terrorist, to ensure that the discretionary } \\
\text { grounds of dual criminality are not used in the future to } \\
\text { prevent the extradition of individual terrorists. }\end{array}$ \\
\hline \multicolumn{2}{|l|}{$\begin{array}{l}\text { Other Forms of Co-operation (R.32 } \\
\& 40, \& \text { SR.V) }\end{array}$} \\
\hline \multicolumn{2}{|l|}{ 7. Other Issues } \\
\hline \multicolumn{2}{|l|}{$\begin{array}{l}\text { Other relevant AML/CFT measures } \\
\text { or issues }\end{array}$} \\
\hline $\begin{array}{l}\text { General framework - structural } \\
\text { issues }\end{array}$ & $\begin{array}{l}\text { Ireland should consider a review of its current and future } \\
\text { requirements of its AML/CFT system; greater collection of } \\
\text { relevant statistics is encouraged and more formal multi- } \\
\text { agency co-operation where appropriate. }\end{array}$ \\
\hline
\end{tabular}

